\title{
The effect of different doses of zinc supplementation on nail elements in elite female athletes
}

\author{
Günay Eskici \\ Department of Coaching Education Faculty of Sport Sciences, \\ Çanakkale Onsekiz Mart University, Canakkale, Turkey
}

\section{abstract}

Background: The trace elements concentration in metabolically inactive fingernails has been used to monitor the exposure to toxic metals or to assess associations between excess or deficiency of trace elements.

Material and methods: The research protocol was applied to a total number of 20 female volleyball players. The subjects who were randomly allocated into two groups with an equal number of members were administered 220 $\mathrm{mg} /$ day (Group 1) and $440 \mathrm{mg} /$ day (Group 2) of zinc sulfat.

Results: The result of the analysis of nail samples collected after 2, 3 and 4 weeks of supplementation showed no significant difference between $\mathrm{Mg}, \mathrm{Ca}, \mathrm{Fe}, \mathrm{Cu}, \mathrm{Se}, \mathrm{P}$ and $\mathrm{Zn}$ levels between the groups $(\mathrm{p}>0.05)$. It was determined that nail $\mathrm{Ca}, \mathrm{Fe}$, and $\mathrm{Zn}$ levels in the last week of zinc supplementation increased significantly compared to the level at the beginning of the supplementation in both groups $(p<0.05)$.

Conclusions: It was determined that two different applications significantly decreased Mg, $\mathrm{P}$ and Se levels for both groups regardless of the dose difference.

Key words: female athletes, nail, trace element, zinc supplementation.

\section{article details}

Article statistics: Word count: 2,368; Tables: 2; Figures: 7; References: 35

Received: September 2020; Accepted: February 2021; Published: June 2021

Full-text PDF: http://www.balticsportscience.com

Copyright @ Gdansk University of Physical Education and Sport, Poland

Indexation: Celdes, Clarivate Analytics Emerging Sources Citation Index (ESCI), CNKI Scholar (China National Knowledge Infrastructure), CNPIEC, DOAJ, EBSCO - Central \& Eastern European Academic Source, EBSCO - SPORTDiscus, EBSCO Discovery Service, Google Scholar, Index Copernicus, J-Gate, Naviga (Softweco, Primo Central (ExLibris), ProQuest - Family Health, ProQuest - Health \& Medical Complete, ProQuest - Illustrata: Health Sciences, ProQuest Nursing \& Allied Health Source, Summon (Serials Solutions/ProQuest, TDOne (TDNet), Ulrich's Periodicals Directory/ ulrichsweb, WorldCat (OCLC)

Funding: This research received no specific grant from any funding agency in the public, commercial, or not-for-profit sectors. The author would like to offer thanks to Berko Food and Chemical Industry Corporation for providing zinc supplement for the study.

Conflict of interests: Author has declared that no competing interest exists.

Assoc. Prof. Günay ESKici; Çanakkale Onsekiz Mart University, Faculty of Sport Sciences, Department of Coaching Education, Canakkale, Turkey; phone no. +90 28621822 97- 3118; e-mail: gunayeskici@comu.edu.tr

Open Access License:

This is an open access article distributed under the terms of the Creative Commons Attribution-Non-Commercial-NoDerivatives 4.0 International (https://creativecommons.org/licenses/by-nc-nd/4.0/), which permits use, distribution and reproduction in any medium, provided the original work is properly cited, the use is non-commercial and is otherwise in compliance with the license. 


\section{INTRODUCTION}

In biochemistry, trace elements are also known as "micronutrients". Trace elements form part of the daily diet and are well known to play vitally important roles in maintaining health [1]. Minimum alterations in their concentrations may induce critical alterations in a person's physiological functions as well as in the physical performance [2].

Zinc is an essential trace element that has been implicated in numerous biological functions, including immunity, energy metabolism and antioxidative processes [3]. As zinc is necessary for many enzymes found in the metabolism, a serious zinc deficiency will have a negative impact on muscle functions [4]. Since zinc is necessary for the activity of several enzymes in the energy metabolism, low muscle zinc levels may lead to a reduction in the endurance capacity [5].

It is known that physical activity leads to many metabolic changes in the human organism; intense training may increase essential trace elements requirements, either by augmented degradation rates or by increased losses from the body [6]. Studies into the relation between zinc and exercise mainly focus on the distribution of this element in the body in response to exercise [7-9].

It was suggested that, since exercise increases zinc excretion from the body, and female athletes in particular do not get enough zinc through diet, zinc supplementation to athletes with zinc deficiency is essential [9]. Recent evaluations of the literature have provided evidence of significant acute changes in zinc metabolism following a bout of aerobic exercise [3].

Zinc and other elements affect absorption of each other when they are taken in excess [10]. Excessive intake of elements such as calcium, phosphorus, iron and copper reduces the absorption of zinc [11], while excessive intake of zinc also reduces absorption of some minerals (iron, copper, calcium, phosphorus and magnesium) [12-13].

Human nails are largely composed of keratin-rich proteins, which accommodate trace metals in proportion to their intake by various mechanisms, such as synthesis of proteins with sulfhydryl groups. Therefore, the nails are a useful marker for trace metals investigation and are increasingly used in clinical studies [14-15]. Their roots are highly influenced by the health status of the cells, whereas blood and other body fluids give transient concentrations, human nails provide a continuous record of elemental concentration [16-19].

The concentration of trace elements in metabolically inactive finger nails has been used to monitor exposure to toxic metals or to assess associations between excess or deficiency of trace elements. The individual's nail's mineral content varies between populations, and not all minerals are deposited in the nails at the same speed. The different elements present in nails have different metabolic roles in the body, and consequently, they could be used as indicators of their nutritional status [18].

An analysis of nail presents advantages over an analysis of biological fluids, such as sweat, urine or blood, because nails can be easily collected and stored at room temperature; moreover, the nail tissue is easier to handle and it also accumulates a large number of trace elements in relatively high concentrations [20-21].

The purpose of the present study was to determine the effect of oral zinc supplementation to elite athletes on the changes in nail element levels. 


\section{MATERIAL AND METHODS}

\section{PARTICIPANTS}

The research was conducted on a total number of 20 female athletes playing in a volleyball team in the Super League of the Sport Club at Gazi University, whose age, bodyweight, and height were $15.1 \pm 1.07$ years (14-17), $59.9 \pm 6.4 \mathrm{~kg}$ (50.4-72.2), and 175.3 \pm 6.5 $\mathrm{cm}$, respectively. The subjects (and/or their parents) who were verbally informed also signed copies of the Helsinki declaration explaining who is conducting the study and why. The study protocol was approved by the Ethical Committee of High School of Physical Education and Sports Selcuk University (meeting number: 2009/005).

The athletes in the study were divided into two groups:

- Group 1: The group was administered $220 \mathrm{mg} /$ day of zinc sulfate (each $220 \mathrm{mg}$ of zinc sulfate contained $50 \mathrm{mg}$ of elemental zinc).

- Group 2: The group was administered $440 \mathrm{mg} /$ day of zinc sulfate (each $440 \mathrm{mg}$ of zinc sulfate contained $100 \mathrm{mg}$ of elemental zinc).

Zinc sulfate capsules were supplied by Berko Drug and Chemicals Industry Inc. in the form of capsules, each containing $220 \mathrm{mg}$ of zinc sulfate.

\section{Procedures}

The study was conducted during the athletes' general preparation period of 8-10 weeks (consisting of $70-80 \%$ power, and $20-30 \%$ technical-tactical exercises).

As the subjects were female athletes, analyses were interrupted in the menstruation weeks. Daily nutrition of the athletes throughout study was kept under control with the nutrition program provided by a dietician. This helped them to have energy and nutrients depending on their personal requirement, and particular attention and care was given to prevent insufficient intake of zinc in the consumption of nutrients.

\section{NaIl MAgNesiUm, CALCIUM, IRON, COPPER, SELENIUM, PHOSPHORUS AND ZINC ANALYSES}

Nail samples were collected from all athletes, who followed their daily training schedule (6 days/week), 5 times: during the resting period before zinc supplementation, and once a week during 4 weeks of zinc supplementation, and during resting period following the supplementation.

Approximately $5 \mathrm{mg}$ of each nail sample was accurately weighed on a microbalance with an accuracy limit of $100 \mu \mathrm{g}$, and put in a teflon vessel, to which $1 \mathrm{~mL}$ of nitric acid was then added. The teflon vessels were placed in a pressure tight case and heated in a microwave oven with the power of $630 \mathrm{~W}$ for 10 minutes. After cooling to room temperature, the vessels were released, and the sample solutions were diluted with purified water to $10 \mathrm{~mL}$. Standard solutions calibrations were prepared by mixing and diluting standard solutions of individual element. $\mathrm{Mg}, \mathrm{Ca}, \mathrm{Fe}, \mathrm{Cu}, \mathrm{Se}, \mathrm{P}$ and $\mathrm{Zn}$ levels $(\mathrm{\mu g} / \mathrm{g})$ in the collected hair samples were determined through Indoctuvely Coupled Plasma Mass Spectrometry (ICPMS) device (AGILENT 7500 ce, Agilent Technologies, Santa Clara, CA 95051-7201 USA).

\section{STATISTICAL ANALYSIS}

The data were evaluated using the Statistical Package for the Social Sciences (SPSS 15.0) where the means and frequency distributions were calculated. Further data analysis was conducted through $\mathrm{t}$ test, and the difference between the groups was determined using Mann Whitney U test. The difference that occurred by weeks was determined through Kruskal-Wallis test. The significance level was considered at $\mathrm{p}<0.05$. 


\section{RESULTS}

\section{Pre-supplementation Nail element levels of the groups}

Analysis of nail samples collected from the athletes before zinc supplementation, showed no significant differences between the groups in $\mathrm{Ca}$, Se and P levels ( $p>0.05)$. A significant difference was found between the athletes' levels of $\mathrm{Mg}, \mathrm{Fe}, \mathrm{Cu}$ and $\mathrm{Zn}$ in Group 1 and 2 $(p<0.05)$, where element levels in Group 1 were higher than those in Group 2 (Figures 1-7),

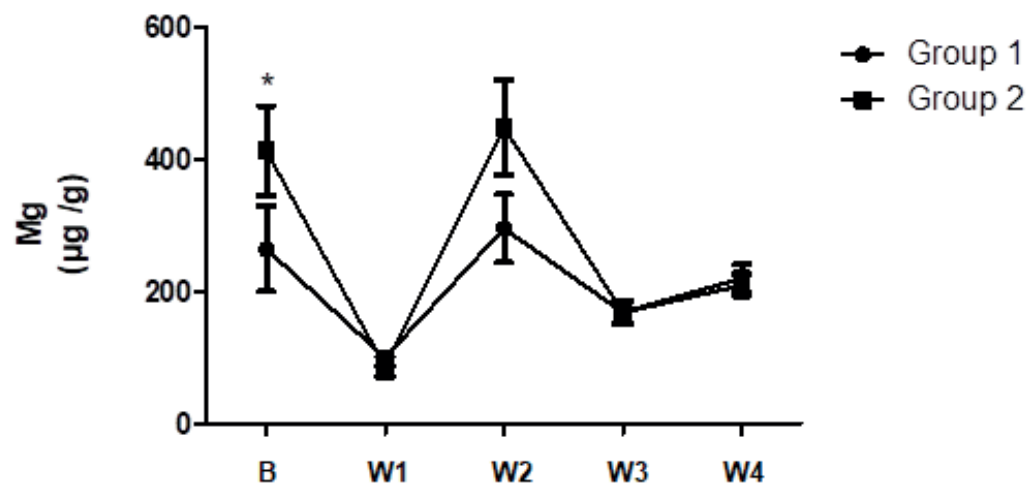

Fig. 1. Nail Mg levels of the groups before supplementation, during supplementation, and after 4 weeks of zinc supplementation

B - before supplementation; W1 - 1 week after supplementation; W2 - 2 weeks after supplementation; W3 - 3 weeks after supplementation; W4 - 4 weeks after supplementation.

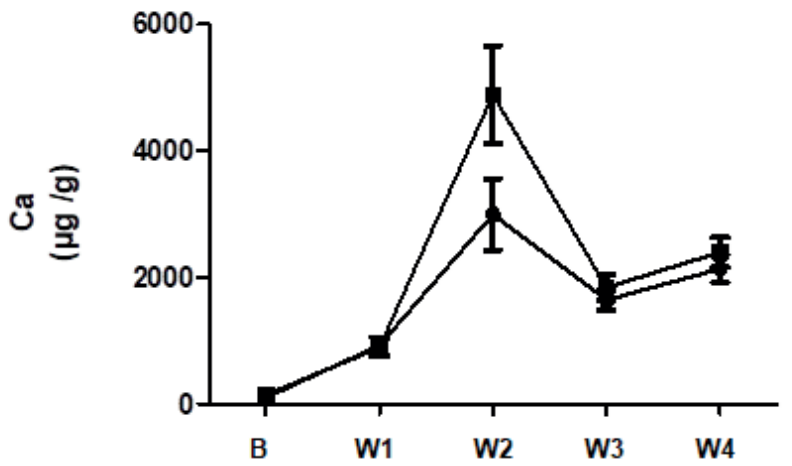

- Group 1
- Group 2

Fig. 2. Nail Ca level of the groups before supplementation, during supplementation, and after 4 weeks of zinc supplementation

B - before supplementation; W1 - 1 week after supplementation; W2 - 2 weeks after supplementation; W3 - 3 weeks after supplementation; W4 - 4 weeks after supplementation.

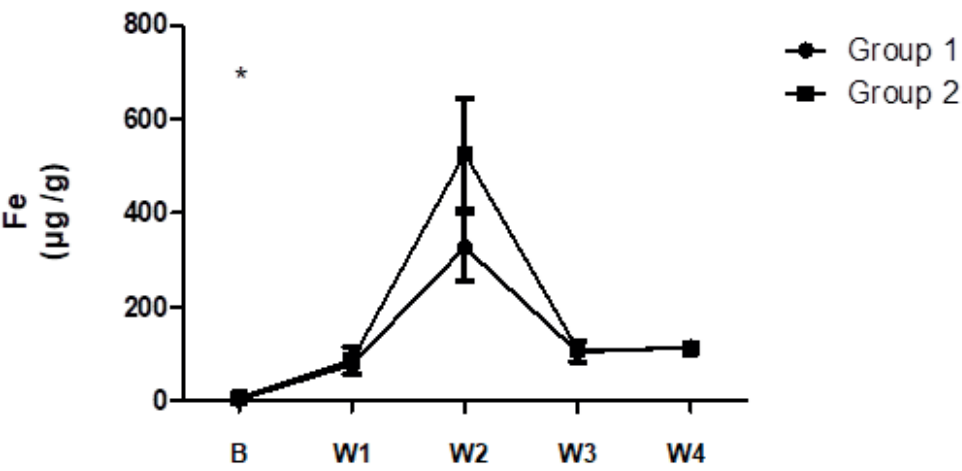

Fig. 3. Nail Fe level of the groups before supplementation, during supplementation, and after 4 weeks of zinc supplementation

B - before supplementation; W1 - 1 week after supplementation; W2 - 2 weeks after supplementation; W3 - 3 weeks after supplementation W4 - 4 weeks after supplementation. 


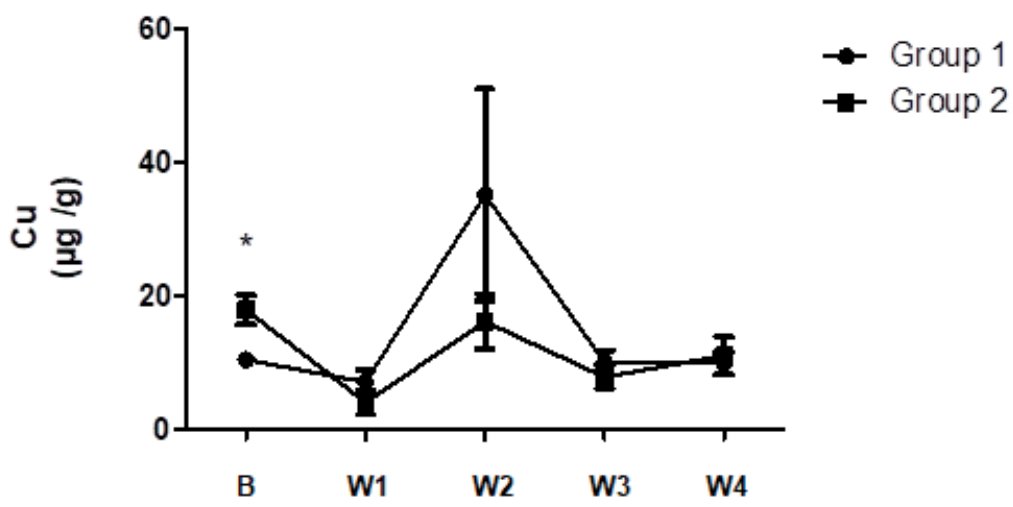

Fig. 4. Nail Cu levels of the groups before supplementation, during supplementation, and after 4 weeks of zinc supplementation

B - before supplementation; W1 - 1 week after supplementation; W2 - 2 weeks after supplementation; W3 - 3 weeks after supplementation; W4 - 4 weeks after supplementation.

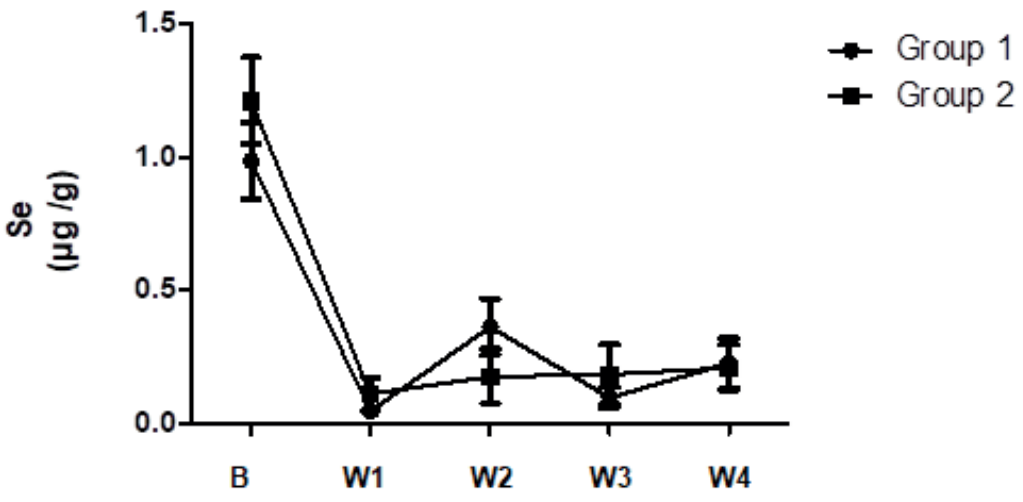

Fig. 5. Nail Se levels of the groups before supplementation, during supplementation, and after 4 weeks of zinc supplementation

B - before supplementation; W1 - 1 week after supplementation; W2 - 2 weeks after supplementation; W3 - 3 weeks after supplementation; W4 - 4 weeks after supplementation.

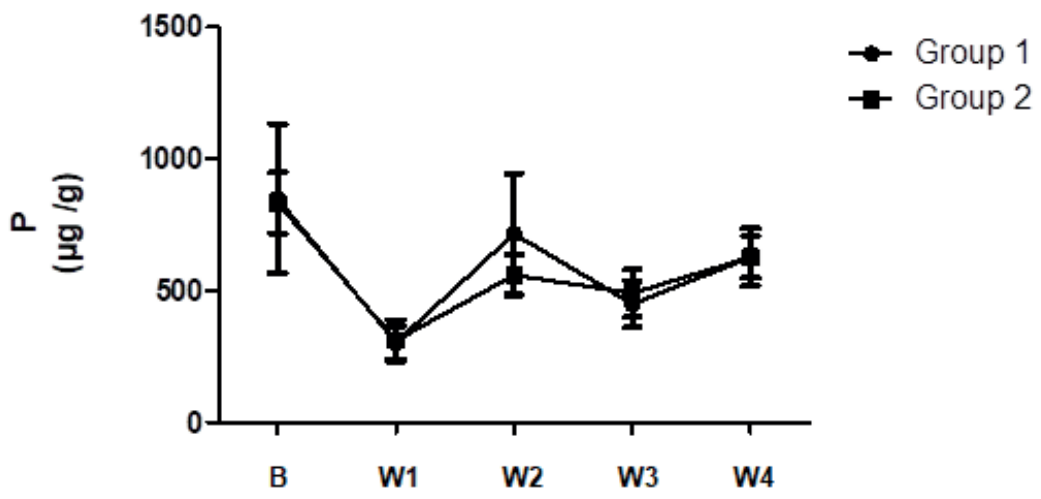

Fig. 6. Nail P levels of the groups before supplementation, during supplementation, and after 4 weeks of zinc supplementation

B - before supplementation; W1 - 1 week after supplementation; W2 - 2 weeks after supplementation; W3 - 3 weeks after supplementation W4 - 4 weeks after supplementation. 


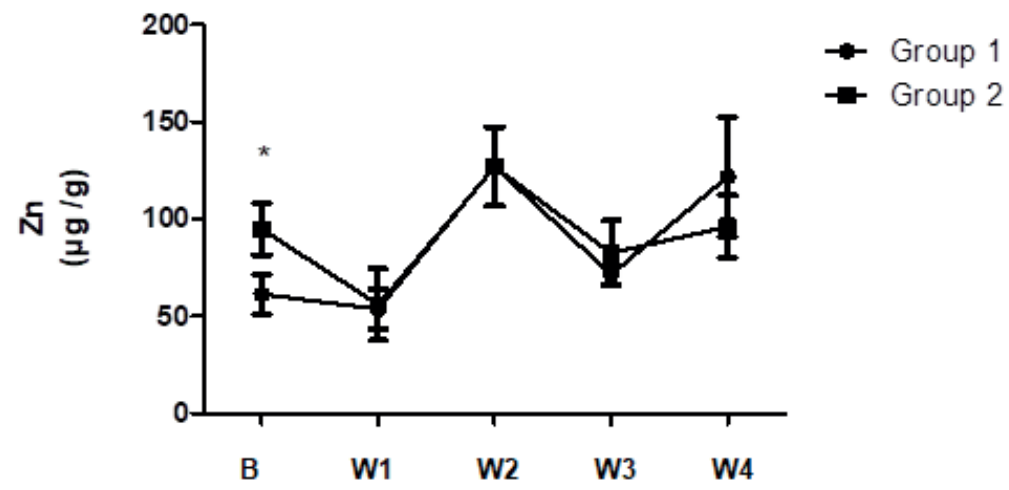

Fig. 7. Nail Zn levels of the groups before supplementation, during supplementation, and after 4 weeks of zinc supplementation

B - before supplementation; W1 - 1 week after supplementation; W2 - 2 weeks after supplementation; W3 - 3 weeks after supplementation; W4 - 4 weeks after supplementation.

COMPARISON BETWEEN THE WEEKLY CHANGES CAUSED BY ZINC SUPPLEMENTATION IN NAIL ELEMENT LEVELS IN GROUPS 1 AND 2

The result of the analysis of nail samples collected after 1,2, 3 and 4 weeks of supplementation showed no significant difference between $\mathrm{Mg}, \mathrm{Ca}, \mathrm{Fe}, \mathrm{Cu}, \mathrm{Se}, \mathrm{P}$ and $\mathrm{Zn}$ levels between the groups ( $p>0.05$, Figures 1-7).

COMPARISON OF THE CHANGES BY WEEKS IN NAIL ELEMENT LEVELS IN GROUP 1 AND GROUP 2 CAUSED BY ZINC SUPPLEMENTATION

Considering the change in the nail element level of the athletes in Group 1 by weeks, zinc supplementation led to a significant change in all elements level by weeks $(p<0.05)$. Nail Mg, P, Cu, and Se levels in the last week of zinc supplementation were found to have significantly decreased compared to the level at the beginning of the supplementation, while $\mathrm{Ca}, \mathrm{Fe}$, and $\mathrm{Zn}$ levels have increased (Table 1).

Considering the change in the nail element level of the athletes in Group 2 by weeks, zinc supplementation led to a significant change in all element levels by weeks $(p<0.05)$. Nail Mg, P and Se levels in the last week of zinc supplementation were found to have significantly decreased compared to the level at the beginning of the supplementation, while $\mathrm{Ca}, \mathrm{Fe}, \mathrm{Cu}$, and $\mathrm{Zn}$ levels have increased (Table 2).

It was found that nail $\mathrm{Ca}, \mathrm{Fe}$, and $\mathrm{Zn}$ levels in the last week of zinc supplementation significantly increased compared to the level at the beginning of the supplementation in both groups (Tables 1 and 2).

Table 1. Changes by weeks in nail element levels in the athletes in group 1caused by zinc supplementation

\begin{tabular}{|c|c|c|c|c|c|}
\hline Elements & Supplementation Time & $\mathrm{N}$ & $\mathrm{X} \pm \mathrm{SS}$ & $\begin{array}{l}\text { Kruskall } \\
\text { Walls' z }\end{array}$ & $\mathrm{p}$ \\
\hline \multirow{5}{*}{$M g(\mu g / g)$} & Before supplementation pre exercise & 10 & $413.86 \pm 214.73$ & \multirow{5}{*}{34.104} & \multirow{5}{*}{$0.000 *$} \\
\hline & 1 weeks after supplementation & 10 & $85.69 \pm 47.24$ & & \\
\hline & 2 weeks after supplementation & 10 & $449.23 \pm 226.74$ & & \\
\hline & 3 weeks after supplementation & 10 & $168.76 \pm 57.95$ & & \\
\hline & 4 weeks after supplementation before exercise & 10 & $220.44 \pm 65.07$ & & \\
\hline \multirow{5}{*}{$P(\mu g / g)$} & Before supplementation pre exercise & 10 & $833.04 \pm 362.53$ & \multirow{5}{*}{17.923} & \multirow{5}{*}{$0.001 *$} \\
\hline & 1 weeks after supplementation & 10 & $310.72 \pm 246.27$ & & \\
\hline & 2 weeks after supplementation & 10 & $559.82 \pm 246.20$ & & \\
\hline & 3 weeks after supplementation & 10 & $491.00 \pm 283.83$ & & \\
\hline & 4 weeks after supplementation before exercise & 10 & $627.08 \pm 253.18$ & & \\
\hline
\end{tabular}




\begin{tabular}{|c|c|c|c|c|c|}
\hline Elements & Supplementation Time & $\mathrm{N}$ & $\mathrm{X} \pm \mathrm{SS}$ & $\begin{array}{l}\text { Kruskall } \\
\text { Walls' z }\end{array}$ & $\mathrm{p}$ \\
\hline \multirow{5}{*}{ Se $(\mu \mathrm{g} / \mathrm{g})$} & Before supplementation pre exercise & 10 & $142.76 \pm 60.79$ & \multirow{5}{*}{41.712} & \multirow{5}{*}{$0.000 *$} \\
\hline & 1 weeks after supplementation & 10 & $893.45 \pm 462.69$ & & \\
\hline & 2 weeks after supplementation & 10 & $4886.10 \pm 2445.08$ & & \\
\hline & 3 weeks after supplementation & 10 & $1842.74 \pm 629.85$ & & \\
\hline & 4 weeks after supplementation before exercise & 10 & $2398.30 \pm 744.53$ & & \\
\hline \multirow{5}{*}{$\mathrm{Fe}(\mu \mathrm{g} / \mathrm{g})$} & Before supplementation pre exercise & 10 & $6.64 \pm 6.48$ & \multirow{5}{*}{36.180} & \multirow{5}{*}{$0.000 *$} \\
\hline & 1 weeks after supplementation & 10 & $86.72 \pm 90.91$ & & \\
\hline & 2 weeks after supplementation & 10 & $526.34 \pm 373.75$ & & \\
\hline & 3 weeks after supplementation & 10 & $110.63 \pm 48.07$ & & \\
\hline & 4 weeks after supplementation before exercise & 10 & $111.68 \pm 20.23$ & & \\
\hline \multirow{5}{*}{$\mathrm{Cu}(\mu \mathrm{g} / \mathrm{g})$} & Before supplementation pre exercise & 10 & $17.88 \pm 7.09$ & \multirow{5}{*}{14.433} & \multirow{5}{*}{$0.006^{*}$} \\
\hline & 1 weeks after supplementation & 10 & $3.97 \pm 5.79$ & & \\
\hline & 2 weeks after supplementation & 10 & $16.14 \pm 13.00$ & & \\
\hline & 3 weeks after supplementation & 10 & $7.78 \pm 5.49$ & & \\
\hline & 4 weeks after supplementation before exercise & 10 & $11.03 \pm 8.88$ & & \\
\hline \multirow{5}{*}{$\mathrm{Zn}(\mu \mathrm{g} / \mathrm{g})$} & Before supplementation pre exercise & 10 & $94.87 \pm 41.64$ & \multirow{5}{*}{12.310} & \multirow{5}{*}{$0.015^{*}$} \\
\hline & 1 weeks after supplementation & 10 & $56.11 \pm 58.26$ & & \\
\hline & 2 weeks after supplementation & 10 & $126.98 \pm 63.77$ & & \\
\hline & 3 weeks after supplementation & 10 & $82.56 \pm 53.19$ & & \\
\hline & 4 weeks after supplementation before exercise & 10 & $96.22 \pm 50.87$ & & \\
\hline \multirow{5}{*}{ Se $(\mu \mathrm{g} / \mathrm{g})$} & Before supplementation pre exercise & 10 & $1.20 \pm 0.51$ & \multirow{5}{*}{22.369} & \multirow{5}{*}{$0.000^{*}$} \\
\hline & 1 weeks after supplementation & 10 & $0.11 \pm 0.20$ & & \\
\hline & 2 weeks after supplementation & 10 & $0.18 \pm 0.32$ & & \\
\hline & 3 weeks after supplementation & 10 & $0.18 \pm 0.36$ & & \\
\hline & 4 weeks after supplementation before exercise & 10 & $0.21 \pm 0.27$ & & \\
\hline
\end{tabular}

$* \mathrm{p}<0.05$

Table 2. Changes by weeks in nail element levels in the athletes in group 2 caused by zinc supplementation

\begin{tabular}{|c|c|c|c|c|c|}
\hline Elements & Supplementation Time & $\mathrm{N}$ & $\mathrm{X} \pm \mathrm{SS}$ & $\begin{array}{l}\text { Kruskall } \\
\text { Walls' z }\end{array}$ & $\mathrm{p}$ \\
\hline \multirow{5}{*}{$\mathrm{Mg}(\mu \mathrm{g} / \mathrm{g})$} & Before supplementation pre exercise & 10 & $264.75 \pm 203.38$ & \multirow{5}{*}{22.531} & \multirow{5}{*}{$0.000 *$} \\
\hline & 1 weeks after supplementation & 10 & $96.23 \pm 40.93$ & & \\
\hline & 2 weeks after supplementation & 10 & $296.12 \pm 163.36$ & & \\
\hline & 3 weeks after supplementation & 10 & $168.30 \pm 47.54$ & & \\
\hline & 4 weeks after supplementation before exercise & 10 & $209.69 \pm 52.17$ & & \\
\hline \multirow{5}{*}{$P(\mu g / g)$} & Before supplementation pre exercise & 10 & $849.54 \pm 893.90$ & \multirow{5}{*}{9.876} & \multirow{5}{*}{$0.043^{*}$} \\
\hline & 1 weeks after supplementation & 10 & $302.53 \pm 201.02$ & & \\
\hline & 2 weeks after supplementation & 10 & $716.15 \pm 725.00$ & & \\
\hline & 3 weeks after supplementation & 10 & $449.42 \pm 280.73$ & & \\
\hline & 4 weeks after supplementation before exercise & 10 & $627.24 \pm 346.06$ & & \\
\hline \multirow{5}{*}{ Se $(\mu \mathrm{g} / \mathrm{g})$} & Before supplementation pre exercise & 10 & $103.45 \pm 64.60$ & \multirow{5}{*}{35.361} & \multirow{5}{*}{$0.000 *$} \\
\hline & 1 weeks after supplementation & 10 & $920.24 \pm 432.54$ & & \\
\hline & 2 weeks after supplementation & 10 & $2995.50 \pm 1783.32$ & & \\
\hline & 3 weeks after supplementation & 10 & $1641.00 \pm 508.16$ & & \\
\hline & 4 weeks after supplementation before exercise & 10 & $2136.90 \pm 700.77$ & & \\
\hline
\end{tabular}




\begin{tabular}{|c|c|c|c|c|c|}
\hline Elements & Supplementation Time & $\mathrm{N}$ & $\mathrm{X} \pm \mathrm{SS}$ & $\begin{array}{l}\text { Kruskall } \\
\text { Walls' z }\end{array}$ & $\mathrm{p}$ \\
\hline \multirow{5}{*}{$\mathrm{Fe}(\mu \mathrm{g} / \mathrm{g})$} & Before supplementation pre exercise & 10 & $3.08 \pm 1.52$ & \multirow{5}{*}{35.197} & \multirow{5}{*}{$0.000^{*}$} \\
\hline & 1 weeks after supplementation & 10 & $78.29 \pm 44.02$ & & \\
\hline & 2 weeks after supplementation & 10 & $327.24 \pm 227.18$ & & \\
\hline & 3 weeks after supplementation & 10 & $104.85 \pm 69.63$ & & \\
\hline & 4 weeks after supplementation before exercise & 10 & $114.41 \pm 44.93$ & & \\
\hline \multirow{5}{*}{$\mathrm{Cu}(\mu \mathrm{g} / \mathrm{g})$} & Before supplementation pre exercise & 10 & $10.36 \pm 2.60$ & \multirow{5}{*}{9.889} & \multirow{5}{*}{$0.042^{*}$} \\
\hline & 1 weeks after supplementation & 10 & $7.04 \pm 5.46$ & & \\
\hline & 2 weeks after supplementation & 10 & $35.12 \pm 50.25$ & & \\
\hline & 3 weeks after supplementation & 10 & $10.05 \pm 5.57$ & & \\
\hline & 4 weeks after supplementation before exercise & 10 & $12.33 \pm 6.33$ & & \\
\hline \multirow{5}{*}{$\mathrm{Zn}(\mu \mathrm{g} / \mathrm{g})$} & Before supplementation pre exercise & 10 & $61.45 \pm 32.2$ & \multirow{5}{*}{18.960} & \multirow{5}{*}{$0.001^{*}$} \\
\hline & 1 weeks after supplementation & 10 & $53.82 \pm 32.72$ & & \\
\hline & 2 weeks after supplementation & 10 & $127.32 \pm 64.07$ & & \\
\hline & 3 weeks after supplementation & 10 & $71.52 \pm 15.74$ & & \\
\hline & 4 weeks after supplementation before exercise & 10 & $121.89 \pm 97.83$ & & \\
\hline \multirow{5}{*}{$\mathrm{Se}(\mu \mathrm{g} / \mathrm{g})$} & Before supplementation pre exercise & 10 & $0.98 \pm 0.45$ & \multirow{5}{*}{29.614} & \multirow{5}{*}{$0.000 *$} \\
\hline & 1 weeks after supplementation & 10 & $0.05 \pm 0.08$ & & \\
\hline & 2 weeks after supplementation & 10 & $0.36 \pm 0.33$ & & \\
\hline & 3 weeks after supplementation & 10 & $0.10 \pm 0.13$ & & \\
\hline & 4 weeks after supplementation before exercise & 10 & $0.23 \pm 0.29$ & & \\
\hline
\end{tabular}

\section{DISCUSSION}

Macro and trace mineral behavior in whole body fluids during physical activity constitutes one of the poorest studied aspects in the field of exercise physiology. The precise link between physical exercise and organic mineral concentrations and redistributions is still unclear. There is a lot of research on the serum and urinary element distributions of exercise [9, 22-25]. In one study, it was found that zinc supplementation raised urinary zinc excretion in one-week intervals over the course of 4 weeks $(p<0.05)$, and reduced selenium levels $(p<0.05)$ [9]. Another study found that zinc supplementation increased serum $\mathrm{Mg}, \mathrm{Ca}, \mathrm{Zn}$ values [25].

Analysis of nail samples collected from the athletes before zinc supplementation showed no significant differences between the groups in the $\mathrm{Ca}$, Se and P levels $(\mathrm{p}>0.05)$. A significant difference was found between $\mathrm{Mg}, \mathrm{Fe}, \mathrm{Cu}$ and $\mathrm{Zn}$ levels of the athletes in Group 1 and $2(\mathrm{p}<0.05)$, where element levels in Group 1 were higher than those of Group 2. The results of the analysis of nail samples collected after 1, 2, 3 and 4 weeks of supplementation showed no significant differences between $\mathrm{Mg}, \mathrm{Ca}, \mathrm{Fe}, \mathrm{Cu}, \mathrm{Se}, \mathrm{P}$ and Zn levels between the groups ( $p>0.05$ ). Nail and hair samples are markers of periods of longer exposure, while urine and blood reflect recent intake, on the order of several days for urine and several weeks for blood [26].

Considering the change in the nail element levels of the athletes in both groups by weeks, zinc supplementation led to a significant change in all elements level by weeks $(p<0.05)$. Nail $\mathrm{Mg}, \mathrm{P}, \mathrm{Cu}$, and Se levels in the last week of zinc supplementation was found to have significantly decreased compared to the level at the beginning of the supplementation, while $\mathrm{Ca}, \mathrm{Fe}$, and $\mathrm{Zn}$ levels have increased in group 1. Nail Mg, P, and Se level in the last week of zinc supplementation was found to have significantly decreased compared to the level at the beginning of the supplementation, while $\mathrm{Ca}, \mathrm{Fe}, \mathrm{Cu}$, and $\mathrm{Zn}$ levels have in- 
creased in group 2. Excessive intake of elements such as calcium, phosphorus, iron and copper reduces the absorption of zinc [11], while excessive intake of zinc also reduces the absorption of some minerals (iron, copper, calcium, phosphorus and magnesium) [12, 13]. This study determined that two different applications significantly decreased $\mathrm{Mg}, \mathrm{P}$ and $\mathrm{Ca}$ levels for both groups regardless of the dose difference.

It was determined that nail $\mathrm{Ca}, \mathrm{Fe}$, and $\mathrm{Zn}$ levels in the last week of zinc supplementation significantly increased compared to the level at the beginning of the supplementation in both groups. In group 2, where the zinc dose was high, the level of nail copper was thought to increase depending on the dose. In another study, the trace element content in women's toenails, but not in men, were markedly influenced by physical activity, with higher levels of $\mathrm{Ca}$ and $\mathrm{Fe}$ and lower $\mathrm{Hg}$ among active females [18].

The role of toenails as a biomarker of supplement intake has been explored for several essential elements, especially for selenium. The use of Se supplements significantly increased toenail Se levels [27-30]. Se was the most studied element, with half of the reports showing a direct relationship of toenail levels with global Se intake [31, 32]. The relationship between the intake of Se supplements and toenail concentration was very consistent, probably due to the high doses of the element in supplements. For other elements (Zn, Mn, Cu), oral supplements were not related to toenail levels; however, there were no data for $\mathrm{Fe}$, another element usually administered in supplements [31].

Among dietary factors, only toenail selenium showed clear associations with the intake of supplements or specific foods [31]. Deficiency in micronutrient can negatively affect athletic performance. Approximately $50 \%$ of athletes have reported consuming some form of micronutrient supplement; however, there is limited data confirming their efficacy for improving performance [33]. In this study, the athletes' food intake was kept under a dietician's control.

The data reveals that the level of elements in the nail can vary depending on gender and age [34]. Age is one of the main factors that could modify toenail metal levels; for example, some studies suggested that age could change the rate of incorporation of elements such as Se into toenails, but also that differences between younger and elder people could reflect age-related variations in the total amount of the element in the body [31]. Determination of inorganic elements in biological samples is important from the viewpoint of the nutritional status or scientific research [35].

Studies on nail element levels of athletes are quite insufficient. Similarly, data on the nail element distribution of zinc supplement application in athletes are insufficient. This $\square$ situation limited a comparison of the results with other studies.

\section{CONCLUSIONS}

At the end of the study, it was found that different doses of zinc sulfate supplementation in elite female athletes who conducted regular trainings on 6 days a week led to no significant difference of nail $\mathrm{Mg}, \mathrm{Ca}, \mathrm{Fe}, \mathrm{Cu}, \mathrm{Se}, \mathrm{P}$ and $\mathrm{Zn}$ levels between the groups. The change in nail element level by weeks in athletes included in Group 1 (220 mg/day zinc sulfate) and Group 2 (440 mg/day zinc sulfate) was found to differ signicifantly with regard to all elements (Mg, Ca, Fe, Cu, Se, P, Zn) levels compared to the beginning of the study. Nail Mg, $\mathrm{P}, \mathrm{Cu}$, and Se levels in the last week of zinc supplementation was found to have significantly decreased compared to the level at the beginning of supplementation, while $\mathrm{Ca}, \mathrm{Fe}$, and $\mathrm{Zn}$ levels have increased in Group 1. Nail Mg, P, and Se levels in the last week of zinc supplementation was found to have significantly decreased compared to the level at the 
beginning of supplementation, while $\mathrm{Ca}, \mathrm{Fe}, \mathrm{Cu}$, and $\mathrm{Zn}$ levels have increased in Group 2. As a result of this study, it was determined that two different applications significantly decreased $\mathrm{Mg}, \mathrm{P}$ and Se levels for both groups regardless of the dose difference.

\section{REFERENCES}

[1] Nasli-Esfahani E, Faridbod F, Larijani B, Ganjali MR, Norouzi P. Trace element analysis of hair, nail, serum and urine of diabetes mellitus patients by inductively coupled plasma atomic emission spectroscopy. Iran J Diabetes Lipid Disord - IJDLD. 2011;10:1-9.

[2] Maynar M, Llerena F, Grijota FJ, et al. Serum concentration of cobalt, molybdenum and zinc in aerobic, anaerobic and aerobic-anaerobic sportsmen. J Int Soc Sports Nutr. 2018;15(1):28. https://doi.org/10.1186/s12970-018-0233-z

[3] Chu A, Holdaway C, Varma T, Petocz P, Samman S. Lower serum zinc concentration despite higher dietary zinc intake in athletes: A systematic review and meta-analysis. Sports Med. 48(2):327-336. https://doi.org/10.1007/ s40279-017-0818-8

[4] Khaled S, Brun JF, Cassanas G, Bardet L, Orsetti A. Effects of zinc supplementation on blood rheology during exercise. Clin Hemorheol Microcirc. 1999; 20:1-10.

[5] Cordova A, Alvarez-Mon M. Behaviour of zinc in physical exercise: a special reference to immunity and fatigue. Neurosci Biobehav Rev. 1995;19:439-445. https://doi.org/10.1016/0149-7634(95)00002-V

[6] Maynar M, Llerena F, Bartolomé I, Alves J, Robles MC, Grijota FJ, Muñoz D. Seric concentrations of copper, chromium, manganesum, nickel and selenium in aerobic, anaerobic and mixed professional sportsmen. J Int Soc Sports Nutr. 2018;15:8. https://doi.org/10.1186/s12970-018-0212-4

[7] Cordova A. Variations in serum iron and fatigue levels after elective abdominal surgery. Med Sci Res 1992;20:119-120.

[8] Dressenderfor RH, Wade CE, Keen CL, Scaff JH. Plasma mineral levels in marathon runners during a 20-day road race. Phys Sportsmed. 1982;10:113-118. https://doi.org/10.1080/00913847.1982.11947250

[9] Eskici G, Gunay M, Baltaci AK, Mogulkoc R. The effect of zinc supplementation on the urinary excretion of elements in female athletes. Pak J Pharm Sci. 2016;29(1):125-129.

[10] Insel P, Turner R E, Ross D. Nutrition. 2nd ed, Jones and Bartlett Publishers: Canada; 2004.

[11] Belgemen T, Akar N. Genes associated with the vital functions of zinc and zinc metabolism. Ankara Üniversitesi Tip Fakültesi Mecmuası. 2004;57:161-166. https://doi.org/10.1501/Tipfak 0000000099

[12] Benardot D. Nutrition for serious athletes. 1st ed, Champaign IL-Human Kinetics: Canada;2000.

[13] Benito P, Miller D. Iron absorption and bioavailability: An updated review. Nutr Res. 1998;18:3581-3603. https:// doi.org/10.1016/S0271-5317(98)00044-X

[14] Favaro PC, Bode P, Nadai Fernandes EA De. Trace elements in nail polish as a source of contamination of nail clippings when used in epidemiological studies. J Radioanal Nucl Chem. 2005;264(1):61-65. https://doi.org/10.1007/ s10967-005-0675-z

[15] Janbabai G, Alipour A, Ehteshami S, Borhani SS, Farazmandfar T. Investigation of Trace elements in the hair and nail of patients with stomach cancer. Indian J Clin Biochem. 2018;33:450-455. https://doi.org/10.1007/s12291-017-0693-y

[16] Abdulrahman FI, Akan JC, Chellube ZM, Waziri M. Levels of heavy metals in human hair and nail samples from Maiduguri Metropolis, Borno State, Nigeria. World Environment. 2012;2(4):81-89. https://doi.org/10.5923/j.env.20120204.05

[17] Martin-Moreno JM, Gorgojo L, Riemersma RA, et al. Myocardial infarction risk in relation to zinc concentration in toenails. Br J Nutr. 2003;89:673-678. https://doi.org/10.1079/BJN2003825

[18] Sureda A, Bibiloni MDM, Julibert A, et al. Trace element contents in toenails are related to regular physical activity in older adults. PLoS One. 2017;12(10):e0185318. https://doi.org/10.1371/journal.pone.0185318

[19] Wilhelm M, Hafner D, Lombeck I, Ohnesorge FK. Monitoring of cadmium, copper, lead and zinc status in young children using toenails: comparison with scalp hair. Sci Total Environ. 1991;103:199-207. https://doi.org/10.1016/00489697(91)90145-5

[20] Aguiar AR, Saiki M. Determination of trace elements in human nail clippings by neutron activation analysis. J Radioanal Nucl Chem. 2001;249(2):413-416. https://doi.org/10.1023/A:1013235123875

[21] Cheng TP, Morris JS, Koirtyohann SR, Spate VL, Baskett CK. Study of the correlation of trace elements in carpenters' toenails. J Radioanal Nucl Chem. 1995;195(1):31-42. https://doi.org/10.1007/BF02036470

[22] Maynar M, Muñoz D, Alves J, et al. Influence of an acute exercise until exhaustion on serum and urinary concentrations of molybdenum, selenium, and zinc in athletes. Biol Trace Elem. Res 2018;186(2):361-369. https://doi.org/10.1007/ s12011-018-1327-9

[23] Marques LF, Donangelo CM, Franco JG, et al. Plasma zinc, copper, and serum thyroid hormones and insulin levels after zinc supplementation followed by placebo in competitive athletes. Biol Trace Elem Res. 2011;142(3);142:415423. https://doi.org/10.1007/s12011-010-8821-z

[24] Kilic M, Baltaci AK, Gunay M. Effect of zinc supplementation on hematological parameters in athletes. Biol Trace Elem Res 2004;100(1):31-38. https://doi.org/10.1385/BTER:100:1:031

[25] Eskici G, Gunay M, Baltaci AK, Mogulkoc R. The effect of different doses of zinc supplementation on serum element and lactate levels in elite volleyball athletes. J Appl Biomed. 2017;15:133-138. https://doi.org/10.1016/j.jab.2016.11.001

[26] Ebrahim AM, Eltayeb M, Benker B, et al. Study on some trace element contents in serum and nail samples obtained from Sudanese subjects. Biol Trace Elem Res. 2011;144(1-3):225-233. https://doi.org/10.1007/s12011-011-9076-z

[27] Baskett CK, Morris JS, Spate VL, et al. The effect of an enriched selenium-76 supplement on dietary monitors and glutathione peroxidase activity. J Radioanal Nucl Chem. 1998;236:39-45. https://doi.org/10.1007/BF02386315

[28] Baskett CK, Spate VL, Mason MM, et al. Long-term selenium status in humans. J Radioanal Nucl Chem. 2001;249(2):429435. https://doi.org/10.1023/A:1013295325692 
[29] Brockman JD, Guthrie JM, Morris JS, Davis J, Madsen R, Robertson JD. Analysis of the toenail as a biomonitor of supra nutritional intake of Zn, Cu, and Mg. J Radioanal Nucl Chem. 2009;279(2):405-410. https://doi.org/10.1007/ s10967-007-7279-3

[30] Guthrie JM, Brockman JD, Morris JS, Robertson JD. The "OneSource" cohort-evaluating the suitability of the human toenail as a manganese biomonitor. J Radioanal Nucl Chem. 2008;276(1):41-47. https://doi.org/10.1007/s10967007-0407-7

[31] Gutiérrez-González E, García-Esquinas E, de Larrea-Baz NF, et al. Toenails as biomarker of exposure to essential trace metals: A review. Environ Res. 2019;179(Pt A):108787. https://doi.org/10.1016/j.envres.2019.108787

[32] Morris JS, Crane SB. Selenium toxicity from a misformulated dietary supplement,adverse health effects, and the temporal response in the nail biologic monitor. Nutrients. 2013;5(4):1024-1057. https://doi.org/10.3390/nu5041024

[33] Heffernan SM, Horner K, De Vito G, Conway GE. The role of mineral and trace element supplementation in exercise and athletic performance: A systematic review. Nutrients. 2019;11(3):E696. https://doi.org/10.3390/nu11030696

[34] Vance DE, Ehmann WD, Markesbery WR. Trace element content in fingernails and hair of a nonindustrialized US control population. Biol Trace Elem Res. 1988;17:109-121. https://doi.org/10.1007/BF02795450

[35] Otag A, Hazar M, Otag I, Gürkan AC, Okan I. Responses of trace elements to aerobic maximal exercise in elite sportsmen. Glob J Health Sci. 2014;6:90-96. https://doi.org/10.5539/gjhs.v6n3p90 